\title{
Specify KIT Exons Assessed
}

National Cancer Institute

\section{Source}

National Cancer Institute. Specify KIT Exons Assessed. NCI Thesaurus. Code C160583.

A request to enter the KIT exons assessed for mutations in this section of the form. 